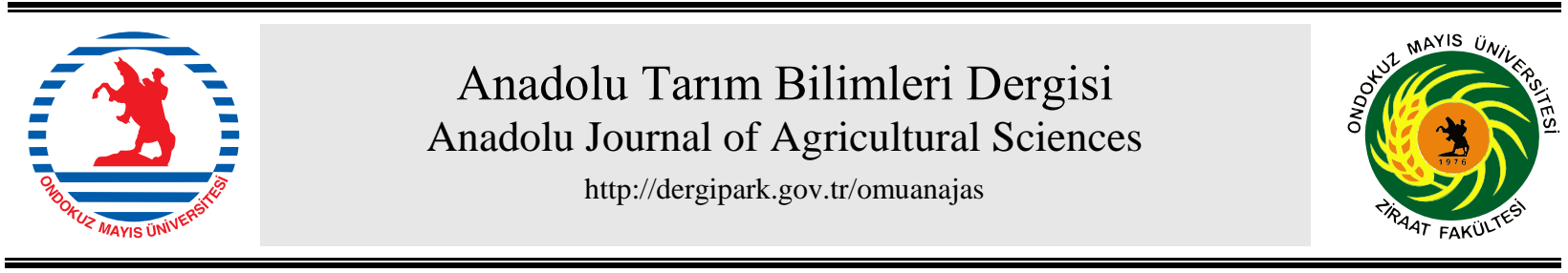

\section{Araştırma/Research}

Anadolu Tarım Bilim. Derg./Anadolu J Agr Sci, 36 (2021) ISSN: 1308-8750 (Print) 1308-8769 (Online) doi: 10.7161/omuanajas.916699

\title{
Ekmeklik buğdayda geliştirilen rekombinant kendilenmiş hat popülasyonunda kalite özellikleri için fenotipik ve genotipik değişim
}

\author{
(1)Nevzat Aydın ${ }^{\mathrm{a}}$, BBedrettin Demir ${ }^{\mathrm{a}}$, DTuğba Güleç ${ }^{\mathrm{b}^{*}}$, Demal Şermet ${ }^{\mathrm{c}}$, \\ (1) Hasan Orhan Bayramoğlu ${ }^{\mathrm{c}}$, (1)Abdulvahit Sayaslan ${ }^{\mathrm{d}}$, (1)Zeki Mut ${ }^{\mathrm{e}}$

\footnotetext{
${ }^{a}$ Karamanoğlu Mehmetbey Üniversitesi, Mühendislik Fakültesi, Biyomühendislik Bölümü, Karaman, Türkiye

${ }^{\mathrm{b}}$ Karamanoğlu Mehmetbey Üniversitesi, TBMYO, Bitkisel ve Hayvansal Üretim Bölümü, Karaman, Türkiye ${ }^{\mathrm{c}}$ Karadeniz Tarımsal Araștırma Enstitüsü, Samsun, Türkiye

${ }^{\mathrm{e}}$ Bilecik Şeyh Edebali Üniversitesi, Ziraat ve Doğa Bilimleri Fakültesi, Tarla Bitkileri Bölümü, Bİlecik, Türkiye
} \\ ${ }^{d}$ Karamanoğlu Mehmetbey Üniversitesi, Mühendislik Fakültesi, Gıda Mühendisliği Bölümü, Karaman, Türkiye
}

*Sorumlu yazar/: tuba.eserkaya@gmail.com

Geliş/Received /15/04/2021 Kabul/Accepted 01/07/2021

\begin{abstract}
ÖZET
Rekombinant kendilenmiş hat popülasyonları tarımsal araştırmalarda kullanılan önemli haritalama popülasyonlarıdır. Çalışmada, Tosunbey ve Tahirova-2000 çeşitleri melezlenerek 420 ve 362 adet hat bulunan resiprokal rekombinant kendilenmiş hat popülasyonu geliştirilmiştir. Popülasyonların geliştirilmesinde tek tohum soy yöntemi kullanılmıştır. $\mathrm{F}_{7}$ generasyondaki homozigot hatlar, Samsun lokasyonunda Agumented deneme desenine göre $6 \mathrm{~m}^{2}$ alanındaki parsellerde yetiştirilmiştir. Hatların Yüksek ve Düşük Molekül Ağırlıklı Glutenin Alt Üniteleri (YMA-GA ve DMA-GA) ile çavdar translokasyonu varlığ SDS-PAGE yöntemiyle belirlenmiştir. Tosunbey çeşidi YMA-GA için 1, 17+18, $5+10$ alt ünitelerini ve DMA-GA için $G l u A 3 b$, GluB3b ve GluD3b allellerini taşırken, Tahirova-2000 çeşidi YMA-GA için 2*, 7+9, 5+10 alt ünitelerini ve DMA-GA için GluA3e, GluB3j ve GluD3b allellerini ve $1 B L .1 R S$ çavdar translokasyonu taşımaktadır. Denemede tane verimi, bitki boyu, başaklanma gün süresi gibi agronomik özellikler yanında protein içeriği, SDS sedimentasyon değeri, hektolitre ağırlığı, bin tane ağırlığı, kül oranı ve L renk değeri saptanmıştır. Tosunbey $\times$ Tahirova-2000 ve Tahirova-2000 $\times$ Tosunbey popülasyonlarında denemelerin ortalama tane verimi sırasıyla $399.5 \mathrm{~kg}$ $\mathrm{da}^{-1}$ ve $328.9 \mathrm{~kg} \mathrm{da}{ }^{-1}$ dır. Popülasyonlarda bitki boyu ve başaklanma süresi için önemli seviyede transgresif açılım gözlenmiştir. Üç yüz yirmi dört hattın çavdar translokasyonu (1BL.1RS) taşıdığ ve çavdar translokasyonunun protein kalitesine etkisinin olumsuz olduğu saptanmıştır. GluA3b alleli taşıyan hatların SDS sedimentasyon değeri, GluA3e alleli taşıyanlara kıyasla daha yüksektir. Araştırma sonuçları popülasyonların ekmeklik buğdayda kalite ve kuraklık çalışmalarında kullanılabilecek elit materyale sahip olduğunu göstermiştir.
\end{abstract}

Phenotypic and genotypic variation for quality traits in the recombinant inbred line population developed in bread wheat

\section{ABSTRACT}

Recombinant inbred line (RILs) populations are substantial mapping populations used in agricultural research. In the study, a reciprocal recombinant inbred line population with 420 and 362 lines was developed by crossing Tosunbey and Tahirova-2000 varieties. The single-seed descent method was used to create the mapping populations. RILs in the $\mathrm{F}_{7}$ generation were grown in plots in a $6 \mathrm{~m}^{2}$ area according to the Augmented design in Samsun location. The presence of rye translocation and High and Low Molecular Weight Gluten Subunits (HMW-GS and LMW-GS) of the lines was determined by the SDS-PAGE method. Tosunbey variety has $1,17+18,5+10$ subunits for YMA-GA and GluA3b, GluB3b, GluD3b alleles for LMW-GS, while Tahirova-2000 variety has $2 *, 7+9,5+10$ subunits for HMW-GS and GluA3e, GluB3j, GluD3b alleles for DMA-GA and $1 B L .1 R S$ rye translocation. The data of grain
Anahtar Sözcükler: Ekmeklik buğday

Rekombinant kendilenmiş hatlar YMA ve DMA glutenin Çavdar translokasyonu
Keywords: Bread wheat RILs HMW-GS and LMWGS Rye translocation 
yield, plant height, and heading time were recorded as agronomic traits, while protein content, SDS sedimentation value, hectoliter weight, thousand-grain weight, ash ratio, and L color value as the quality traits. The average grain yield of Tosunbey $\times$ Tahirova-2000and Tahirova-2000 $\times$ Tosunbey populations is $399.5 \mathrm{kgda}^{-1}$ and $328.9 \mathrm{kgda}^{-1}$, respectively. Significant transgressive segregation was observed for plant height and heading time in the mapping populations. Three hundred twenty-four lines have rye translocation(1BL.1RS), and the effect of rye translocation on protein quality was negative. The SDS sedimentation value of the lines with the GluA3b allele is higher than those with the GluA3e allele. These results indicated that the populations have the elite lines for bread wheat quality and drought studies.

\section{Giriş}

Buğday, farklı ploidi seviyesinde türlere ve büyük bir genoma sahip olması yanında ekim ve kullanım alanının geniş olması nedeniyle yoğun ıslah araştırmalarının yapıldığı önemli bir kültür bitkisidir (Rabinovich, 1998; Reynolds ve ark., 2011). Ekonomik öneme sahip tarımsal özellikler için genotip $\times$ çevre interaksiyonunun belirlenmesi, bu özellikleri kontrol eden genlerin moleküler olarak tespiti ve sslah programları için elit materyallerin geliştirilmesi diğer bitkilerde olduğu gibi buğday ıslahında da önemli araştırma konularıdır (Poland ve ark., 2012; Reynolds ve ark., 2011). Rekombinant kendilenmiş hat popülasyonları homozigot bireylerde çalışma imkânı sağlaması ve geliştirilen hatlardaki yüksek rekombinasyon oranı gibi avantajlar nedeniyle sslah programlarında kullanılan önemli haritalama popülasyonlarıdır ( $\mathrm{Hu}$ ve ark., 2020). Haritalama popülasyonu olarak $\mathrm{F}_{2}$ generasyonundaki hatlar, geriye melez döller ve double haploid popülasyonlar da kullanılmaktadır (Assanga ve ark., 2017). Son yıllarda moleküler çalışmaların hızlı arışı, haritalama popülasyonlarının kullanımı ve bu popülasyonlara olan ihtiyacı artırmıştır. Moleküler çalışmalar sonucunda ekonomik öneme sahip özelliklere ilişkin genotipik bilgilerin belirlenmesi yanında ön ıslah (Pre-breeding) çalışmaları kapsamında sslah programlarına elit genotipler de kazandırılmaktadır.

Islah programlarının en önemli amaçlarından biri verim potansiyeli yüksek çeşitlerin geliştirilmesidir. Buğdayda tane verimi çok genle kontrol edilen ve çevreden önemli seviyede etkilenen bir özelliktir (Peterson ve ark., 1992). Birçok ülkede tane verimi bakımından hedef bölgeye uygun stratejinin belirlenmesinde; başaklanma süresi ve bitki boyu önemli rol oynamaktadır (Wilhelm ve ark., 2013). Bununla birlikte, Basavaraddi ve ark. (2021) başaklanma süresi ve bitki boyu arasındaki pleiotropik etkiye benzer özellikler dışında gelecekteki tahıl veriminin artırılabilmesi için yüksek performans bağlamında faydalı özelliklerin belirlenmesi gerektiğini bildirmişlerdir. Başaklanma süresi, kuraklıktan kaçış veya ilkbaharda düşen yağışlardan daha etkin şekilde faydalanmak için, bitki boyu ise kuraklık geldiği anda bitkinin saplarında bulunan depo fotosentez ürün miktarının kısa boylu bitkilerden daha fazla olması nedeniyle kuraklık çalışmalarında büyük önem taşımakta ve seleksiyon kriteri olarak kullanılmaktadır (Faheem ve ark., 2015; Dreisigacker ve ark., 2016).

Buğdayda kalite, kullanım amacına göre geniş bir anlam ifade etmektedir. Bu nedenle, buğdayda "kabul edilebilir son kullanım kalitesi" terimi oldukça anlamlıdır. Protein kalitesi, daha çok genetik olarak kontrol edilmekte olduğu ve protein kalitesi üzerine yetiştiriciliğin etkisinin daha az olduğu bildirilmiştir (Anonim, 1990; Peterson ve ark., 1992; Atl1, 1999). Özellikle yüksek tane verimi elde edilen ürünlerde protein oranının nispi oranının azalması nedeniyle protein oranı ve tane verimi arasındaki ilişki bazı araştırmacılar tarafından belirlenmiştir (Cook, 1992; Costa ve Kronstad, 1994).

Buğdayda glutenin proteinleri, Yüksek Molekül Ağırlıklı (YMA) ve Düşük Molekül Ağırlıklı (DMA) olmak üzere ikiye ayrılmaktadır (Hsia ve Anderson, 2001). Ǘç gen lokusu tarafindan kontrol edilen YMA glutenin alt üniteleri grup 1 kromozomlarının (1AL, 1BL ve 1DL) uzun kolunda lokalize olmuştur ve lokuslar Glu-1A, Glu-1B ve Glu-1D olarak tanımlanmıştır (Payne ve ark., 1987).

YMA glutenin alt üniteleri buğdayın kalitesi ile yakından ilişkilidir. Payne (1987) her bir alt ünite için SDS sedimantasyon değerine göre bir kalite skoru belirlemiştir ve bu skor genellikle tutarlılık göstermektedir. Buğdayda sodium dodecyl sulfate (SDS) sedimantasyon test sonuçlarının \%65-70 oranında YMA glutenin alt üniteleri ile açıklanabileceği ve bu iki ölçütün birlikte kullanılması ile ekmeklik olma kalitesi iyi çeşitlerin daha kolay seçilebileceği belirtilmiştir (Summers ve Payne, 1997). Buna göre, farklı lokuslarda yer alan 1, 17+18 ve 5+10 YMA glutenin alt üniteleri kalite bakımından en yüksek skorlara sahiptir. Bununla birlikte, Baenziger ve ark. (2001) düşük kalite genleri olarak bilinen 2+12 YMA glutenin alt ünitesi taşıyan ve kabul edilebilir kaliteye sahip çeşitler de geliştirmişlerdir. DMA glutenin alt üniteleri, YMA glutenin alt ünitelerine oranla daha az araştırılmıştır. Bunun nedeni, moleküler olarak tespitinin daha zor olması yanında gliadin proteinleriyle yakından bağlantılı olmasıdır (D’Ovidio ve Masci, 2004). Son yıllarda geliştirilen markörler ve SDS-PAGE yöntemindeki optimizasyon sonucu, DMA glutenin alt ünitelerinin kalite ve diğer agronomik özellikler üzerine etkisine ilişkin önemli araştırmalar yapılmıştır (Ram ve ark., 2011; Espi ve ark., 2014; Bonafede ve ark., 2015). 
Çavdar translokasyonları, buğdayın stres şartlarına uyum yeteneği, hastalıklara dayanıklılık, verim potansiyeli ve adaptasyon yeteneğini artırmak amacıyla buğday 1slahında kullanılan önemli bir genetik kaynaktır (Graybosch, 2001; Ehdaie ve ark., 2011). Literatürün büyük bir çoğunluğu çavdar translokasyonlarının agronomik performansı artırırken, buğday kalitesini olumsuz yönde etkilediğini ortaya koymuştur (Martin ve Stewart, 1990; Graybosch 2001; Lelleya ve ark., 2004; Moiraghi ve ark., 2013). Çavdar translokasyonu taşıyan genotiplerde kalitenin düşük olması genellikle Glu-B3 lokusunda bulunan DMA glutenin alt ünitelerinin bulunmaması ve çavdardan transfer edilen secalin proteinini içermesindendir. Graybosch (2001), çavdar translokasyonu taşıyan genotiplerin kalite özelliklerini iyileştirmeyi hedefleyen popülasyonlar geliştirilirken ebeveynden birinin güçlü glutene sahip olması ve ideal YMA glutenin alt ünitelerini taşıması gerektiğini bildirmiştir.

Buğday yetiştiriciliğinde, özellikle nispi nem ve yağışın yüksek olduğu bölgelerde hem verimde hem kalitede önemli düşüşlere yol açan hastalıklarının başında külleme (Erysiphe graminis sp. tritici) gelmektedir. Külleme, Karadeniz Bölgesi'nde her sene doğal şartlarda epidemi yapmaktadır. Türkiye'de islah programlarında bulunan buğday materyalinin büyük çoğunluğu küllemeye karşı hassastır. Bu duruma nispi nemin düşük olduğu bölgelerde hastalığın epidemi yapmamasının etkisi önemlidir. Islah programlarında küllemeye karşı dayanıklılıkta genellikle ırk özellikli dayanıklılık (Race-specific resistance) kullanılmaktadır. Irk özellikli dayanıklılık küllemenin bazı izolatlarına dayanıklılık sağlarken, diğer bazı izolatlarına dayanıklılık sağlamamaktadır (Liu ve ark., 2001). Diğer bir dayanıklılık tipi ise olgun bitki dayanıklılığıdır (Adult plant resistance veya tarla dayanıklılığı) ve ırk özellikli dayanıklılığa oranla daha uzun süreli dayanıklılık sağlamaktadır.

$\mathrm{Bu}$ araştırmada, tek tohum soy yöntemi ile geliştirilen resiprokal kendilenmiş hat popülasyonunda hatların YMA ve DMA glutenin alt üniteleri ile çavdar translokasyonunun varlığı yanında bazı agronomik, kalite özellikleri ve hatların küllemeye dayanıklılıkları saptanmıştır.

\section{Materyal ve Yöntem}

Rekombinant kendilenmiş hat popülasyonlarının geliştirilmesinde ebeveyn olarak Tosunbey ve Tahirova-2000 ekmeklik buğday çeşitleri kullanılmıştır. Tosunbey çeşidi, Tarla Bitkileri Merkez Araştırma Enstitüsü (Ankara), Tahirova-2000 çeşidi ise Mısır Araştırma Enstitüsü (Sakarya) tarafından geliştirilmiştir. Çeşitler genel olarak tane verim potansiyeli, başaklanma süresi, protein kalitesi, protein miktarı ve külleme hastalığına dayanıklılık bakımından farklılık göstermektedir. Ebeveyn çeşitlere ait bazı özellikler Çizelge 1'de verilmiştir. Denemelerde araştırma enstitüsü tarafından geliştirilen Altındane çeşit adayı da kullanılmıştır. Altındane, yazlık karakterli olup, beyaz başaklı, beyaz daneli ve kılçıklı bir çeşittir. Başakları olgunlaşma sürecinde aşağı doğru eğilmektedir. Başaklanma gün sayısı bakımından orta erkenci grupta yer almaktadır. Optimum koşullarda 80-100 cm boya sahiptir. Pas hastalıklarına (Sarı pas, Kara pas ve Kahverengi pas) ve küllemeye karşı dayanıklıdır. Soğuk zararına ve başakta çimlenmeye orta hassas, yatmaya karşı dayanıklıdır.

\subsection{Rekombinant kendilenmiş hatların geliştirilmesi}

Rekombinant kendilenmiş hatların geliştirilmesinde tek tohum soy yöntemi (Single Seed Descent) kullanılmıştır (Brim, 1966). $\mathrm{F}_{2}$ generasyonundan itibaren bütün generasyonlarda her bir bitkiden tesadüfi olarak bir tohum alınarak bir sonraki generasyon yetiştirilmiştir. Popülasyonlar, $F_{6}$ generasyonu da dahil olmak üzere serada yetiştirilmiştir. $F_{6}$ generasyonu tek başak sırası olarak toprak zeminli serada tek başak sıraları şeklinde yetiştirilmiş ve elde edilen tohumlar $\mathrm{F}_{7}$ generasyonu olarak tarlada verimde nemesi ve hastalık okuma setlerinde kullanılmıştır. Sitoplazmik etkilerin araştırılabilmesi amacıyla melezlemeler resiprokal olarak yapılmıştır. Tosunbey $\times$ Tahirova-2000 melezinden 420 adet, Tahirova-2000 × Tosunbey melezinden 362 adet homozigot hat geliştirilmiştir.

\subsection{Hastalık okuma setlerinin hazırlanması ve hastalık okumaları}

Hastalık okumaları için hatlar ve ebeveyn (Kate-A1) tek sıra ve 2 tekerrürlü olarak Samsun lokasyonunda ekilmiştir. Hastalık gözlem bahçelerinde hastalık epidemi seviyesinin kontrolü amaciyla her 10 sirada 1 sıra küllemeye hassas olan Kate-A1 çeşidi yer almıştır. Ayrıca hastalık okuma setlerinde küllemeye dayanıklılık sağlayan Pm21 genini taşıyan translokasyon hattı da yer almıştır (Yıldırım ve ark., 2004). Hatların külleme okumaları doğal epidemi şartlarında yapılmıştır. Külleme hastalık okumaları, Saari ve Prescott (1975) tarafindan geliştirilen ve buğdayda yaprak hastalıklarının yoğunluğunun değerlendirildiği skalaya göre yapılmıştır. Ayrıca reaksiyon tipi hassas (S), orta hassas (MS), orta dayanıklı (MR) ve dayanıklı (R) şeklinde saptanmıştır (Roelfs ve ark., 1992). 


\begin{tabular}{|c|c|c|}
\hline Özellikler & Tosunbey & Tahirova-2000 \\
\hline Verim potansiyeli (iyi çevrede) ** & $500-700 \mathrm{~kg} \mathrm{da}^{-1}$ & $600-900 \mathrm{~kg} \mathrm{da}^{-1}$ \\
\hline Bitki boyu** & $95-100 \mathrm{~cm}$ & $90-95 \mathrm{~cm}$ \\
\hline Bodurluk genleri $*$ & Rht-Dla (wild), Rht 8 (192 bp) & $\begin{array}{l}\text { Rht-Bla (wild), Rht-Dla (wild), } \\
\text { Rht } 8 \text { (192 bp) }\end{array}$ \\
\hline Başaklanma gün sayısı** & 121 gün & 125 gün \\
\hline Gelişme tabiatı & Alternatif & Yazlık \\
\hline Vernalizasyon allelleri $* * *$ & $V r n-A 1 b, V r n-B 1, v r n-D 1$ & Vrn-Ala, vrn-B1, Vrn-D1 \\
\hline Tane rengi $* *$ & Beyaz & Beyaz \\
\hline Unda protein oran ${ }^{* *}$ & $\% 12-15$ & $\% 11-13$ \\
\hline Unda SDS Sedimentasyon hacmi** & $35 \mathrm{ml}$ & $19 \mathrm{ml}$ \\
\hline YMA Glutenin alt üniteleri** & $1,17+18,5+10$ & $2^{*}, 7+9,5+10$ \\
\hline DMA Glutenin alt üniteleri** & Glu A3b, Glu B3b, Glu D3b & Glu A3e (null), Glu B3j, Glu D3b \\
\hline Çavdar translokasyonu $* * *$ & Yok & $\operatorname{Var}(1 B L .1 R S)$ \\
\hline Tane sertliği** & Sert & Sert \\
\hline Tane sertliği* & $\begin{array}{c}\text { Pina }(\text { Pina-Dla }(-), \text { Pina-Dlb }(-) \\
\text { Pinb }(\text { Pinb-Dla }(-), \text { Pinb-Dlb (+), } \\
\text { Pinb-Dl c (-)) }\end{array}$ & $\begin{array}{c}\text { Pina }(\text { Pina-Dla }(-), \text { Pina-Dlb }(-) \\
\text { Pinb (Pinb-Dla }(-), \text { Pinb-Dlb (+), } \\
\text { Pinb-Dl c (-)) }\end{array}$ \\
\hline Hektolitre ağırlığ $1 * *$ & $74.7-80.5 \mathrm{~kg}$ & $78-82.5 \mathrm{~kg}$ \\
\hline Bin tane ağırlığ $1 * *$ & $26.2-34.7 \mathrm{~g}$ & $34-40 \mathrm{~g}$ \\
\hline Waxy gen allelleri** & $W x-A 1(+), W x-D 1(+), W x-B 1(-)$ & $W x-A 1(+), W x-D 1(+), W x-B 1(+)$ \\
\hline Küllemeye dayanıklılık** & Hassas & Dayanıklı \\
\hline
\end{tabular}

* Özkan H. TÜBİTAK Projesi Sonuç Raporu, $107 \mathrm{O} 207$

** Aydın N. TÜBİTAK Projesi Sonuç Raporu, 1120135

*** Güleç T. Doktora Tezi

\subsection{Verim denemelerinin yürütülmesi}

Resiprokal melezleme sonucu elde edilen iki farklı popülasyonda bulunan hatlar iki farklı deneme şeklinde Samsun ilindeki Karadeniz Tarımsal Araştırma Enstitüsü'nün araştırma arazilerinde (deniz seviyesinden yüksekliği 4 m, Lat. $41^{\circ} 13^{\prime}$ N Lon. 36º $30^{\prime}$ E) 2010-2011 yetiştirme sezonunda test edilmiştir. Agumented deneme desenine göre tekerrürsüz olarak kurulan denemeler de ebeveyn çeşitler ve araştırma enstitüsü tarafından geliştirilen Altındane çeşit adayı kullanılmıştır. Her bir blokta 20 hat ve 3 kontrol çeşit yer alacak şekilde deneme 6 metre uzunluğundaki parsellere sıra arası $20 \mathrm{~cm}$ ve 6 sıra olacak şekilde ve kontrol çeşitler her blokta yer alacak şekilde yapılmıştır. Denemeler, deneme mibzeriyle ekilmiş (Wintersteiger) ve parsel hasat-harman biçerdöveri (Hege 160) ile hasat edilmiștir. Hasatta parsel alanı $6 \mathrm{~m}^{2}$ olacak şekilde planlanmıştır. Gübreleme, dekara $6 \mathrm{~kg}$ saf azot ekimle birlikte, 6 $\mathrm{kg} \mathrm{da}^{-1}$ sapa kalkma döneminde ve $3 \mathrm{~kg} \mathrm{da}^{-1}$ çiçeklenme döneminde olmak üzere toplam $15 \mathrm{~kg}$ saf azot şeklinde yapılmıştır.

\subsection{Incelenen agronomik ve kalite özellikleri}

Parselden elde edilen tane verimi dekara çevrilmiş ve tane verimi $\mathrm{kg} \mathrm{da}^{-1}$ olarak ifade edilmiştir. Bitki boyu, toprak yüzeyinden başaktaki son başakçı̆̆ın ucuna kadar olan mesafe ölçülerek belirlenmiş ve değerler cm olarak ifade edilmiştir. Başaklanma süresi, 1 Ocak tarihinden itibaren parseldeki bitkilerin yaklaşık olarak \% 50'si başaklanıncaya kadar geçen süre gün sayısı olarak ifade edilmiştir (Tavella, 1978; Bohn ve ark., 1998). Hektolitre ağıllıkları, hektolitre kabı kullanılarak (AACC Metot 55-10) belirlenmiş ve kg olarak ifade edilmiştir. Her bir genotipten dört kez 100 adet tohum otomatik tohum sayma makinesi (Chopin-Numigral-I) ile sayılmış ve ortalaması alınıp 10 ile çarpılarak bin tane ağırlıkları gram olarak hesaplanmıştır. Tam buğday unlarının protein içerikleri Perten Inframatic 9500 cihazının (Perten Instruments, Sweden) un modülü kullanılarak belirlenmiş ve \%14 nem içeriğine göre yüzde olarak ifade edilmiştir. Buğday unlarının kül oranı Perten Inframatic 9500 cihazının un modülü kullanılarak belirlenmiştir ve \% olarak ifade edilmiştir. Buğday unlarının L renk değeri Perten Inframatic 9500 cihazının un modülü kullanılarak belirlenmiştir. Tam buğday unu örneklerinin protein kalitelerinin göstergesi olan 
sodyum dodesil sülfat (SDS) sedimantasyon hacimleri Maghirang ve ark. (2006) ve Sayaslan ve ark. (2006) tarafindan modifiye edilen AACC yöntemi (AACC Metot 56-70) takip edilerek ölçülmüştür.

\subsection{Incelenen moleküler özellikler}

2.5.1. YMA ve DMA molekül ă̆ırlıkl glutenin alt ünitelerinin belirlenmesi

Buğday genotiplerinin YMA ve DMA glutenin alt üniteleri, Masci ve ark. (2000) ve Gianibelli ve ark. (2002) tarafindan tanımlanan ve Koyuncu (2009) tarafindan modifiye edilen Sodyum Dodesil Sülfat Poliakrilamid jel elektroforez (SDS-PAGE) yöntemine göre belirlenmiş ve Singh ve ark. (1991) tarafindan belirtilen yönteme göre okunmuştur.

\subsection{2. Çavdar translokasyonunun belirlenmesi}

Çavdar translokasyonunun belirlenmesinde YMA ve DMA glutenin alt ünitelerinin belirlendiği SDS-PAGE jeller kullanılmıştır. Bilindiği üzere $1 B L .1 R S$ çavdar translokasyonu taşıyan genotiplerde 1B kromozomunun kısa kolunda çavdar translokasyonu bulunduğu için buğdaya ait YMA glutenin alt üniteleri bulunmamaktadır. Bu yüzden Glu-B3 lokusu boştur ve jelde çavdara özel protein bantları yer almaktadır.

\subsection{Verilerin de ğerlendirilmesi ve istatistik analiz}

Genotiplerin kalite ve agronomik özellikleri ile YMA ve DMA glutenin alt ünitelerinin kalite ve agronomik özellikleri üzerine etkileri JMP istatistik paket programında Agumented deneme desenine göre analiz edilmiştir (JMP 12.0.1).

\section{Bulgular ve Tartışma}

\subsection{Hatların agronomik ve kalite özellikleri}

Resiprokal popülasyonlar tane verimi bakımından karşıllaştııldığında Tosunbey $\times$ Tahirova-2000 popülasyonunun yer aldığı denemenin ortalama tane veriminin $\left(399.5 \mathrm{~kg} \mathrm{da}^{-1}\right)$ Tahirova-2000 $\times$ Tosunbey popülasyonunun yer aldığ 1 denemenin ortalama tane veriminden $\left(328.9 \mathrm{~kg} \mathrm{da}^{-1}\right)$ daha yüksek olduğu görülmektedir (Çizelge 2 ve 3 ). Ayrıca, Tosunbey $\times$ Tahirova-2000 popülasyonda yer alan hatlar daha yüksek tane verimine sahip olmuş ve bu hatların, tane verimi 106-636 kg da ${ }^{-1}$ arasında değişmiştir (Çizelge 3). Hatlar arasındaki bu büyük verim farklılı̆̆ının nedeninin büyük ihtimalle deneme yerinden kaynaklandığı düşünülmektedir. Zira, her ne kadar denemeler aynı ada içerisinde ve yan yana yer alsa bile deneme alanlarının çok geniş olması $(40 \mathrm{~m} \times 133 \mathrm{~m})$ tane veriminde önemli farklılıkların nedeni olabilir. Birçok bitkide olduğu gibi buğdayda da tane verimi çevreden etkilenen, kalıtım derecesi düşük ve çok genle kontrol edilen bir özelliktir (Peterson ve ark., 1992). Ayrıca, tane verimi üzerine genotiplerin kalıtsal özelliklerinin etkisi de önemlidir (Major ve ark., 1992; Genç ve ark., 1993). Tane verimi hakkında daha ayrıntılı yorum yapabilmek için hatların farklı yıl ve lokasyonlarda yetiştirilmesi gerekmektedir. Bununla birlikte geliştirilen haritalama popülasyonundan seçilen 145 hattın yer aldığı ve sekiz farklı çevrede yürütülen denemelerin ortalama tane verimi yaklaşık dekara $580 \mathrm{~kg}$ 'dır (Veriler yayınlanmamıştır).

Resiprokal popülasyonların bitki boyu bakımından deneme ortalamaları benzerdir $(102.5 \mathrm{~cm}$ ve $102.9 \mathrm{~cm})$. Ortaya çıkan açılımda ebeveyn çeşitlerden kısa boylu olan bitkilerin oranı, her iki popülasyonda da (\% 54 ve \% 67) uzun boylu bitkilerin oranından (\% 22 ve \% 28) daha yüksektir (Çizelge 2 ve 3). Popülasyonlarda bu yönde bir transgresif açılımın görülmüş olması ıslah programları için önemlidir. Kısa boylu bitkiler genellikle yatmaya daha dayanıklı olabilmekte ve yüksek verim amacıyla daha yüksek oranlarda gübreleme yapılmasına firsat vermektedir. Bazı araştırmacılar, kısa boylu çeşitlerin uzun boylu çeşitlerden daha verimli olduğunu bildirmişlerdir (McClung ve ark., 1986; Blade ve Baker, 1991). Kisa boylu genotipler $\mathrm{CO}_{2}$ 'den daha fazla yararlanabilmeleri nedeni ile daha yüksek verim potansiyeli sahip olabilmektedir (Fischer ve ark., 1981).

Popülasyonların yer aldığı denemelerin ortalama başaklanma gün sayısı 133 gündür (Çizelge 2 ve 3). Her iki popülasyonda da ebeveynden daha geç başaklanan hatların sayısı, daha erken başaklanan hatların sayısından fazladır. Bu durum bize transgresif açılımın geç başaklanma yönünde daha fazla gerçekleştiğini göstermektedir. Bu sonuçlar elde edilen popülasyonların başaklanma süresi bakımından oldukça geniş bir değişime sahip olduğunu göstermektedir. Buğdayda başaklanma süresi transgresif açılımın yoğun olarak görüldüğü özelliklerdendir.

Resiprokal popülasyonların ortalama SDS sedimantasyon değeri birbirine yakın olmakla birlikte, ekmeklik kalitesi daha iyi olan Tosunbey çeşidinin ana olarak kullanıldığ (Çizelge 2 ve 3). Popülasyonlarda SDS sedimantasyon değeri bakımından ortaya çıkan açılım büyük oranda ebeveyn çeşitlerin değerleri arasında gerçekleşmiştir. Bununla birlikte, Tosunbey çeşidinden daha yüksek değere 
sahip hat sayısı, her iki popülasyonda da Tahirova-2000 çeşidinden daha düşük değere sahip hat sayısının iki katından fazladır. $\mathrm{Bu}$ sonuç, transgresif açılımın yüksek SDS sedimantasyon değeri yönünde daha fazla gerçekleştiğini göstermektedir. Islah programlarında 1slahçılar ekmeklik kalitesi yüksek çeşitler geliştirmek için genellikle $30 \mathrm{ml}$ 'nin üzerinde SDS sedimantasyon değerine sahip olan hatları seçmektedirler. Çalışmada, $30 \mathrm{ml}$ üzerinde SDS sedimantasyon değerine sahip hat sayısı Tosunbey $\times$ Tahirova-2000 popülasyonunda 269 adet $(\%$ 71), Tahirova-2000 x Tosunbey popülasyonunda ise 159 adet $(\%$ 45) adettir. Çevresel faktörlerden daha az etkilenen (Graybosch ve ark., 1996), analizi basit, tekrarlanabilirliği yüksek, yoğun olarak kullanılan ve genotiplerin ekmek olma kabiliyeti hakkında güvenilir sonuçlar veren bir kalite kriteri (Moonen ve ark., 1982) bakımından böyle bir açılımının ortaya çıkmış olması araştırma açısından ve popülasyonların buğday kalitesi konusunda yapılacak araştırmalara konu olması bakımından önemlidir.

Hektolitre ağırlığı bakımından Tosunbey $\times$ Tahirova-2000 popülasyonunun daha yüksek ortalamaya sahip olduğu ve bu popülasyonda yer alan hatların hektolitre ağırlıklarının daha yüksek olduğu görülmektedir (Çizelge 2 ve 3). Her iki popülasyonda da transgresif açılım oranı hektolitre ağıllı̆̆nın yüksek olduğu yönde gerçekleşmiştir. Hektolitre ağırlığı tanenin şekli, sertliği ve un verimi ile yakından ilişkili bir kalite kriteridir (Schuler ve ark., 1994; Sade ve ark., 1999). Bitki ıslahçıları ve un sanayii hektolitre ağırlı̆̆ı için ürünün sahip olması gereken minimum değerin 76-78 kg'ın üzerinde olmasını istemektedir (Anonim, 2010).

Her iki popülasyon bin tane ağırlığı bakımından karşılaştırıldığında Tosunbey $\times$ Tahirova-2000 popülasyonunun Tahirova-2000 $\times$ Tosunbey popülasyonundan daha yüksek değere sahip olduğu görülmektedir (Çizelge 2 ve 3 ). Tosunbey $\times$ Tahirova-2000 popülasyonunun bin tane ağırlığı 31.3 ile 55.3 g arasında değişirken, Tahirova-2000 $\times$ Tosunbey popülasyonunun bin tane ağırlığı 27.0 ile $48.3 \mathrm{~g}$ arasında değişmiştir. Bin tane ağırlığı buğdayda un miktarının tahmin edilmesinde önemli bir ölçü kriteridir. Çünkü küçük tanelerde endospermin, endosperm olmayan kısma oranı, büyük taneli olanlara göre daha düşük olmaktadır (Mut ve ark., 2007). Bin tane ağırlığı sadece verimle ilgili değil aynı zamanda kaliteyle de ilişkilidir. Bu özelliğe etkili iki önemli faktör, genetik yapı ve ekolojik faktörlerdir (Mut ve ark., 2007).

\subsection{Hatların külleme hastalığına karşı reaksiyonları}

Tarla okumalarına göre külleme hastalığına reaksiyonlarının toplam yüzde oranlarına bakıldığında dağılımın her iki popülasyonda da birbirine çok yakın değerlere sahip olduğu görülmektedir. Bununla birlikte, dayanıklı hat sayısı ile orta seviyede dayanıklı hat sayısı bakımından popülasyonlar farklı dağılım göstermiştir (Çizelge 4 ve 5). Bu sonuçların alınmasında örneklemenin çok fazla sayıda hatta yapılmış olması ve her bir hatta ait dört farklı külleme okumasının yapılmış olmasının etkili olduğu düşünülmektedir. Ebeveyn olarak kullanılan Tosunbey çeşidi küllemeye hassas, Tahirova-2000 çeşidi ise dayanıklı reaksiyon göstermiştir. Popülasyonda yer alan hatlar küllemeye dayanıklılık bakımından normal dağılım göstermiş oldukları için Tahirova-2000 çeşidinde küllemeye dayanıklılığı sağlayan birden fazla genin bulunduğunu veya Tosunbey çeşidinde ilgili hastalıkla ilgili bir genin bulunduğu ama tek başına dayanıklılık sağlamadığı söylenebilir. Ayrıca tarla okumalarında hatların neredeyse hiçbirinin sıfir skoru almaması ve Tahirova-2000 çeşidinin 3 skorunu almış olması nedeniyle olgun bitki dayanıklılığından söz edilebilir. Hastalık okuma setlerinde kontrol genotip olarak yer alan küllemeye dayanıklılık geni olan Pm21 genini tek başına taşıyan translokasyon hattı sıfır skoru almıştır. Bu gen bölgedeki külleme irklarına karşı dayanıklı genotiplerin geliştirilmesinde kullanılabilir. Buğdayda külleme hastalığı tane verimini (Johnson ve ark., 1979; Griffey ve ark., 1993) ve kaliteyi olumsuz yönde etkilemektedir (Everts ve ark., 2001). Hastalı̆̆ın kontrolünde en uygun yöntem dayanıklı genotiplerin geliştirilmesidir. Bitkilerde dayanıklılık ırk özellikli dayanıklılık ve olgun bitki dayanıklılığı olarak ikiye ayrılabilir. Olgun bitki dayanıklılığı birden fazla genle dayanıklılık sağladığı için ırk özellikli dayanıklılığa oranla daha uzun süreli dayanıklılık sağlayabilmektedir (Lillemo ve ark., 2008).

1BL.1RS çavdar translokasyonuna sahip olan genotiplerin, buğdayda küllemeye dayanıklılık geni olan Pm7 genini taşıdığı bildirilmiştir (Singh ve ark., 1991; Hsam ve ark. 2000). Araştırma sonucunda, Tahirova-2000 çeşidinin küllemeye dayanıklılığının birden fazla genle kontrol ediliyor olduğunun belirlenmiş olması 1slah programları için önemlidir.

\subsection{Hatların taşıdığı YMA ve DMA glutenin alt üniteleri}

Genotipik açılıma göre elde edilen hatların YMA ve DMA glutenin alt üniteleri bakımından 16 farklı kombinasyona sahip olması beklenmektedir ve bu durum popülasyonda yapılan moleküler analizler ile de teyit edilmiş̧ir (Şekil 1 ve 2). Her iki popülasyondaki hatların sayısı dikkate alındığında çavdar translokasyonu (Glu-B3j) taşıyan hat sayısı toplam 324 adettir. Ebeveyn çeşitler 5+10 bantlarını ve Glu-D3b allelini taşıdığı için Çizelge'de bu allellere yer verilmemiştir. Tosunbey $\times$ Tahirova-2000 popülasyonunda protein kalitesini olumlu yönde etkileyen GluA3b ve GluB3b DMA glutenin alt ünitelerini taşıyan hat sayısı 109 adet, Tahirova-2000 × Tosunbey 
popülasyonu için ise bu sayı 129 adettir (Çizelge 5). Bu hatların Türkiye buğday kalite ıslah araştırmaları için genetik kaynak olarak ve yeni araştırmaların planlanmasında kullanılabilme potansiyeli bulunmaktadır.

Çizelge 2. Tosunbey $\times$ Tahirova-2000 popülasyonunun $\mathrm{F}_{7}$ generasyonundaki hatların agronomik ve kalite özelliklerine ilişkin değerler

Table 2. Agronomic and quality traits of Tosunbey $\times$ Tahirova-2000 population in $F_{7}$ generation

\begin{tabular}{lcccccc}
\hline & $\begin{array}{c}\text { Tane } \\
\text { verimi } \\
(\mathrm{kg} / \mathrm{da})\end{array}$ & $\begin{array}{c}\text { Bitki boyu } \\
(\mathrm{cm})\end{array}$ & $\begin{array}{c}\text { Başaklanma } \\
\text { gün sayısı } \\
\text { (gün) }\end{array}$ & $\begin{array}{c}\text { SDS } \\
\text { Sedim. } \\
\text { Değeri (ml) }\end{array}$ & $\begin{array}{c}\text { Hektolitre } \\
\text { ağırlığı }(\mathrm{kg})\end{array}$ & $\begin{array}{c}1000 \text { tane } \\
\text { ağırlığı }(\mathrm{g})\end{array}$ \\
\hline Tahirova-2000 & 501 & 106 & 133 & 26 & 82.2 & 43.1 \\
Tosunbey & 400 & 108 & 129 & 36 & 80.7 & 39.8 \\
Altındane & 415 & 88 & 128 & 49 & 79.0 & 38.9 \\
Ortalama & 399.5 & 102.5 & 133 & 32.1 & 81.7 & 41.7 \\
Maksimum & 636.0 & 126 & 144 & 49 & 86.8 & 55.3 \\
Minimum & 106.0 & 78 & 122 & 18 & 75.3 & 31.3 \\
DK \% & 14.8 & 4.4 & 2 & 9 & 1.1 & 4.7 \\
SH & 69 & 5.1 & 3.1 & 3.4 & 1 & 2.2 \\
\hline
\end{tabular}

DK: Değişim katsayısı, SH: Standart hata

Çizelge 3.Tahirova-2000 $\times$ Tosunbey popülasyonunun $\mathrm{F}_{7}$ generasyonundaki agronomik ve kalite özelliklerine ilişkin değerler

Table 3.Agronomic and quality traits of Tahirova-2000 $x$ Tosunbey population in $F_{7}$ generation

\begin{tabular}{lcccccc}
\hline & $\begin{array}{c}\text { Tane } \\
\text { verimi } \\
(\mathrm{kg} / \mathrm{da})\end{array}$ & $\begin{array}{c}\text { Bitki boyu } \\
(\mathrm{cm})\end{array}$ & $\begin{array}{c}\text { Başaklanma } \\
\text { gün sayıs1 } \\
\text { (gün) }\end{array}$ & $\begin{array}{c}\text { SDS } \\
\text { Sedim. } \\
\text { Değeri (ml) }\end{array}$ & $\begin{array}{c}\text { Hektolitre } \\
\text { ağırlı̆̆ }(\mathrm{kg})\end{array}$ & $\begin{array}{c}1000 \text { tane } \\
\text { ağırlı̆̆ }(\mathrm{g})\end{array}$ \\
\hline Tahirova-2000 & 378 & 104 & 133 & 23 & 78.6 & 36.3 \\
Tosunbey & 301 & 107 & 129 & 31 & 76.7 & 34.3 \\
Altındane & 332 & 88 & 126 & 44 & 75.3 & 33.3 \\
Ortalama & 328.9 & 102.9 & 133 & 28.8 & 78.3 & 35.9 \\
Maksimum. & 571 & 122 & 145 & 45 & 84.1 & 48.3 \\
Minimum & 79 & 81 & 118 & 19 & 68.7 & 27.0 \\
DK \% & 16.5 & 5 & 2 & 9 & 1.9 & 7.7 \\
SH & 62.5 & 5.8 & 3 & 3.05 & 1.7 & 3.2 \\
\hline
\end{tabular}

DK: Değişim katsayısı, SH: Standart hata 
Çizelge 4. Popülasyonlarda yer alan hatların $\mathrm{F}_{7}$ generasyonunda tarlada külleme hastalığına karşı reaksiyonlarına ilişkin hat sayıları ve yüzde oranları

Table 4. Line numbers and percentage rates of the lines in the populations regarding their reactions to powdery mildew in the $F_{7}$ generation.

\begin{tabular}{ccccccc}
\hline & \multicolumn{3}{c}{ Tosunbey x Tahirova-2000 } & \multicolumn{3}{c}{ Tahirova-2000 x Tosunbey } \\
\cline { 2 - 6 } Reaksiyon tipi & $\begin{array}{c}\text { Hat sayıs1 } \\
\text { (adet) }\end{array}$ & $\begin{array}{c}\text { Hatların } \\
\text { oranı (\%) }\end{array}$ & $\begin{array}{c}\text { Toplam } \\
\text { oran (\%) }\end{array}$ & $\begin{array}{c}\text { Hat sayıs1 } \\
\text { (adet) }\end{array}$ & $\begin{array}{c}\text { Hatların } \\
\text { oranı (\%) }\end{array}$ & $\begin{array}{c}\text { Toplam } \\
\text { oran (\%) }\end{array}$ \\
\hline Dayanıklı (1-3) & 106 & 25.2 & 31.4 & 43 & 11.9 & 31.2 \\
Orta Seviyede Dayanıkl1 (4) & 26 & 6.2 & & 70 & 19.4 & 47.0 \\
Orta Seviyede Hassas (5-6) & 198 & 47.2 & 47.2 & 170 & 47.0 & 18.5 \\
Hassas (7-8) & 68 & 16.2 & & 67 & 3.3 & \\
Çok Hassas (9) & 22 & 5.2 & 21.4 & 12 & 100 & 100 \\
Toplam & 420 & 100 & 100 & 362 & & \\
\hline
\end{tabular}

Çizelge 5. Popülasyonlarda yer alan hatların taşımış oldukları YMA ve DMA glutenin alt ünitelerine ilişkin hat sayıları

Table 5. Line numbers related to HMW-GS and LMW-GS in the populations

\begin{tabular}{|c|c|c|c|c|c|c|c|c|c|c|c|}
\hline \multicolumn{6}{|c|}{ Tosunbey x Tahirova-2000 } & \multicolumn{6}{|c|}{ Tahirova-2000 x Tosunbey } \\
\hline \multicolumn{3}{|c|}{ YMA alleli } & \multicolumn{2}{|c|}{ DMA alleli } & \multirow{2}{*}{$\begin{array}{l}\text { Hat } \\
\text { Sayıs1 }\end{array}$} & \multicolumn{3}{|c|}{ YMA alleli } & \multicolumn{2}{|c|}{ DMA alleli } & \multirow{2}{*}{$\begin{array}{c}\text { Hat } \\
\text { Say1s1 }\end{array}$} \\
\hline $\begin{array}{c}\text { Glu- } \\
\text { Al }\end{array}$ & Glu-B1 & $\begin{array}{c}\text { Glu- } \\
\text { D1 }\end{array}$ & Glu-A3 & $\begin{array}{c}\text { Glu- } \\
\text { B3 }\end{array}$ & & $\begin{array}{c}\text { Glu- } \\
\text { Al }\end{array}$ & Glu-B1 & $\begin{array}{c}\text { Glu- } \\
D 1\end{array}$ & $\begin{array}{c}\text { Glu- } \\
\text { A3 }\end{array}$ & $\begin{array}{c}\text { Glu- } \\
\text { B3 }\end{array}$ & \\
\hline 1 & $17+18$ & $5+10$ & $\mathrm{~b}$ & $\mathrm{~b}$ & 42 & 1 & $17+18$ & $5+10$ & $\mathrm{~b}$ & $\mathrm{~b}$ & 62 \\
\hline 1 & $17+18$ & $5+10$ & $\mathrm{e}$ & b & 48 & 1 & $17+18$ & $5+10$ & $\mathrm{e}$ & b & 28 \\
\hline 1 & $17+18$ & $5+10$ & $\mathrm{~b}$ & $\mathrm{j}$ & 7 & 1 & $17+18$ & $5+10$ & $\mathrm{~b}$ & $\mathrm{j}$ & 13 \\
\hline 1 & $17+18$ & $5+10$ & $\mathrm{e}$ & $\mathrm{j}$ & 11 & 1 & $17+18$ & $5+10$ & $\mathrm{e}$ & $\mathrm{j}$ & 6 \\
\hline $2 *$ & $17+18$ & $5+10$ & $\mathrm{~b}$ & $\mathrm{~b}$ & 45 & $2 *$ & $17+18$ & $5+10$ & $\mathrm{~b}$ & $b$ & 42 \\
\hline $2 *$ & $17+18$ & $5+10$ & $\mathrm{e}$ & $\mathrm{b}$ & 52 & $2 *$ & $17+18$ & $5+10$ & $\mathrm{e}$ & $\mathrm{b}$ & 30 \\
\hline $2 *$ & $17+18$ & $5+10$ & $\mathrm{~b}$ & $\mathrm{j}$ & 9 & $2 *$ & $17+18$ & $5+10$ & $\mathrm{~b}$ & $\mathrm{j}$ & 7 \\
\hline $2^{*}$ & $17+18$ & $5+10$ & $\mathrm{e}$ & $\mathrm{j}$ & 10 & $2^{*}$ & $17+18$ & $5+10$ & $\mathrm{e}$ & $\mathrm{j}$ & 1 \\
\hline 1 & $7+9$ & $5+10$ & $b$ & $b$ & 7 & 1 & $7+9$ & $5+10$ & $b$ & $b$ & 14 \\
\hline 1 & $7+9$ & $5+10$ & $\mathrm{e}$ & b & 13 & 1 & $7+9$ & $5+10$ & $\mathrm{e}$ & b & 19 \\
\hline 1 & $7+9$ & $5+10$ & $\mathrm{~b}$ & $\mathrm{j}$ & 50 & 1 & $7+9$ & $5+10$ & $\mathrm{~b}$ & $\mathrm{j}$ & 32 \\
\hline 1 & $7+9$ & $5+10$ & e & $\mathrm{j}$ & 28 & 1 & $7+9$ & $5+10$ & $\mathrm{e}$ & $\mathrm{j}$ & 33 \\
\hline $2 *$ & $7+9$ & $5+10$ & $\mathrm{~b}$ & $\mathrm{~b}$ & 15 & $2 *$ & $7+9$ & $5+10$ & $\mathrm{~b}$ & $b$ & 11 \\
\hline $2 *$ & $7+9$ & $5+10$ & $\mathrm{e}$ & $\mathrm{b}$ & 21 & $2^{*}$ & $7+9$ & $5+10$ & $\mathrm{e}$ & $\mathrm{b}$ & 17 \\
\hline $2 *$ & $7+9$ & $5+10$ & $\mathrm{~b}$ & $\mathrm{j}$ & 35 & $2^{*}$ & $7+9$ & $5+10$ & $\mathrm{~b}$ & $\mathrm{j}$ & 21 \\
\hline $2^{*}$ & $7+9$ & $5+10$ & $\mathrm{e}$ & $\mathrm{j}$ & 31 & $2 *$ & $7+9$ & $5+10$ & $\mathrm{e}$ & $\mathrm{j}$ & 30 \\
\hline & & Toplam & & & 424 & & & oplam & & & 366 \\
\hline
\end{tabular}




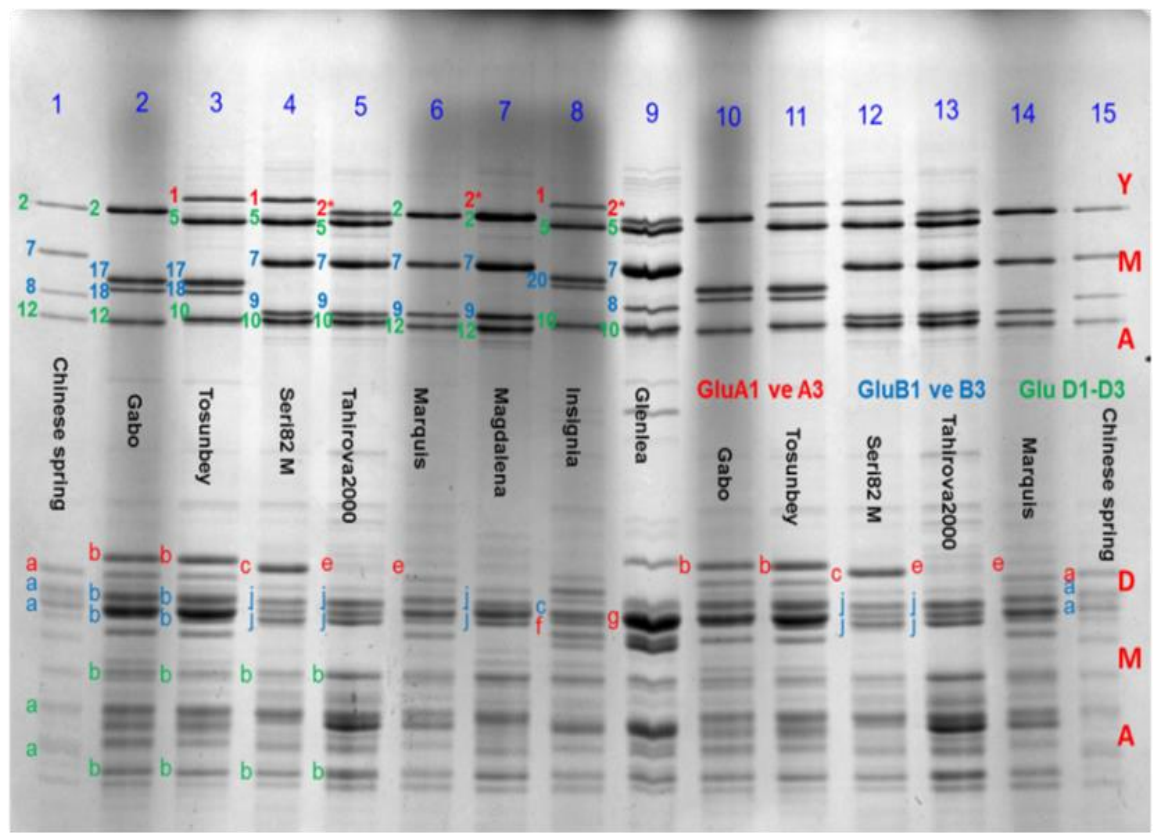

Şekil 1. Ebeveynlerin ve kontrol genotiplerin YMA ve DMA glutenin alt üniteleri.

Figure 1. Subunits of HMW and LMW gluten by parent sand control genotypes.

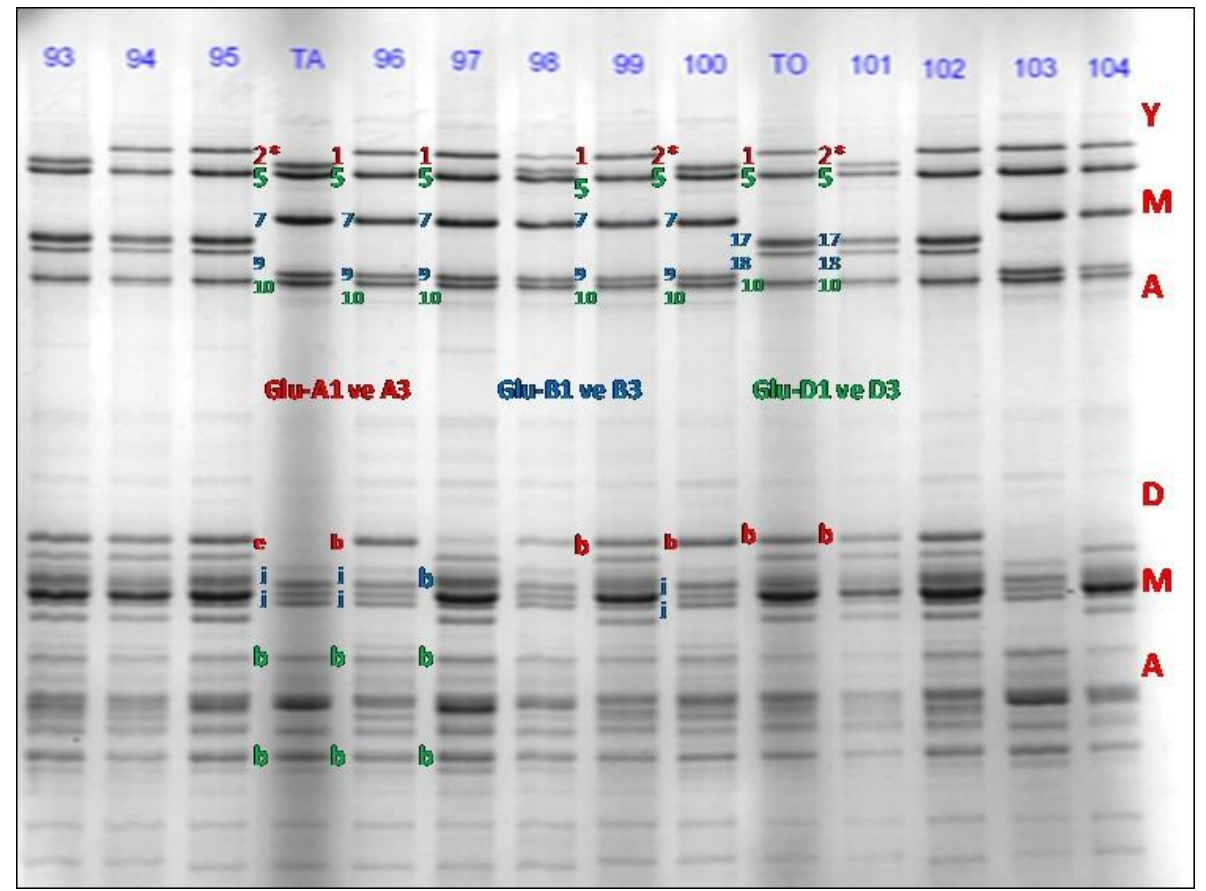

Şekil 2. Ebeveynlerinve bazı hatların YMA ve DMA glutenin alt üniteleri (TA: Tahirova-2000, TO: Tosunbey). Figure 2. Subunits of HMW and LMW gluten by parents and some lines.

\subsection{Hatların agronomik ve kalite özelliklerine YMA ve DMA glutenin alt ünitelerinin etkileri}

Çalışmada, Tosunbey×Tahirova-2000 popülasyonundan 417 adet hatta agronomik ve kalite özellikleri için analizler yapılmıştır. Bu popülasyonda bazı hatlar başka çalışmalarda kullanıldığı için protein içeriği, kül oranı ve L renk değeri analizleri sadece 215 adet hatta (Çizelge 6), diğer analizler ise 417 hatta gerçekleştirilmiştir (Çizelge 7). Tosunbey $\times$ Tahirova-2000 popülasyonunda incelenen özelliklere YMA ve DMA glutenin alt ünite allelerinin 
etkisini gösteren değerler Çizelge 6 ve 7'de verilmiştir. Hatların protein içeriği ve kül oranı çavdar translokasyonu taşıyan hatlarda daha yüksek iken, L renk değeri çavdar translokasyonu taşımayanlarda daha yüksektir (Çizelge 6). Glu-Al lokusundaki 1 alt ünitesini taşıyan hatlar daha yüksek tane verimi ve uzun bitki boyuna sahip olmuşlardır. Popülasyonda yer alan hatların kalite özellikleri üzerine YMA glutenin alt ünitelerindeki değişimin etkisi gözlenmez iken, çavdar translokasyonunun (Glu-B3j) protein içeriği, kül, L renk değeri, SDS sedimentasyon değeri, hektolitre ağırlığı ve bin tane ağırlığına etkisi önemlidir. Çavdar translokasyonu taşıyan hatlar daha düşük sedimentasyon değerine ve daha yüksek protein içeriğine, hektolitre ve bin tane ağırlığına sahiptir. Glu-A3 allelindeki farklılıklar SDS sedimentasyon ve bin tane ağırlığını etkilemiştir. Glu-A3b alleli taşıyan hatlar Glu-A3e alleli taşıyan hatlardan daha yüksek sedimentasyon değerine sahipken, bu hatların bin tane ağırlığının daha düşük olduğu gözlenmiştir.

Tahirova-2000 × Tosunbey melezlemesi sonucu elde edilen popülasyonda 344 adet hatta hem agronomik özellikler hem de kalite özellikleri için analiz yapılmıştır. Tahirova-2000 $\times$ Tosunbey popülasyonunda incelenen özelliklere YMA ve DMA glutenin alt ünitesindeki farklılıkların etkisini gösteren değerlere Çizelge 8 ve 9'da yer verilmiştir. Bu popülasyonda da çavdar translokasyonu taşıyan hatların ortalama olarak daha yüksek protein içerdiğgi saptanmıştır. Bununla birlikte Glu-Al allelinin L renk değeri, tane verimi, bitki boyu ve hektolitre ağırlığına etkisi ve Glu-A3 allelinin protein oranı ve sedimentasyona etkisi önemli bulunmuştur (Çizelge 8). YMA glutenin alt ünitesi olarak 1 alt ünitesini taşıyan hatlar $2^{*}$ alt ünitesini taşıyan hatlara oranla daha yüksek hektolitre ağırlığı, L renk değeri, tane verimi ve bitki boyu değerlerine sahip olmuştur (Çizelge 9). Popülasyonda allelik farklılık gözlenen diğer bir YMA glutenin alt ünitesi Glu-Bllokusunda yer almaktadır ve 17+18 alt ünitesi taşıyan hatlar 7+9 alt ünitesi taşıyan hatlara oranla daha yüksek SDS sedimentasyon değerine sahip iken, daha düşük bitki boyu ve başaklanma gün sayısına sahip olmuştur. Bu sonuç,17+18 alt ünitesine sahip genotiplerin protein kalitesinin daha iyi olduğunu gösteren çalışmalarla uyum içerisindedir (Butow ve ark., 2003; Henkar ve ark., 2017; Guo ve ark., 2019). Glu-A3b DMA alt ünitesi taşıyan hatlar Glu-A3e DMA alt ünitesi taşıyan hatlara oranla daha düşük protein içeriğine sahip olmasına rağmen, daha yüksek SDS sedimentasyon değerine sahip olmuştur. Çavdar translokasyonu taşıyan hatların $(G l u-B 3 j)$ protein içeriği ve bin tane ağırlığı çavdar translokasyonu taşımayan hatlara oranla daha yüksek iken, SDS sedimentasyon değeri daha düşüktür (Çizelge 9).

Her iki popülasyonda da kalite özellikleri üzerine en etkili genetik faktör çavdar translokasyonudur. Elde edilen sonuçlar, çavdar translokasyonunun protein kalitesi üzerine olumsuz etkisini gösteren birçok araştırma sonucuyla benzerlik göstermektedir (Zeller ve Hsam, 1984; Dhaliwal ve MacRitche, 1990; Graybosch, 2001; Moiraghi ve ark., 2013). Popülasyonlarda çavdar translokasyonunun varlığ 1 tane verimi, bitki boyu ve başaklanma süresi gibi özellikler üzerinde etkili olmadığı belirlenmiştir.

Kalite özellikleriyle yakından ilişkili YMA glutenin alt ünitelerinin genel olarak agronomik özellikler üzerine etkili olmadığı görülmüştür. Bununla birlikte Glu-Al lokusu her iki popülasyonda da tane verimi ve bitki boyu üzerinde etkili olmuştur. Tahirova-2000 × Tosunbey popülasyonunda Glu-B1 lokusunun başaklanma gün sayısına etkisi de önemlidir.

Tosunbey $\times$ Tahirova-2000 popülasyonunda yer alan çavdar translokasyonu taşıyan hatların başaklanma gün sayıları 123 gün ile 143 gün arasında, bitki boyu ise $78-126 \mathrm{~cm}$ arasında değişmiştir. Aynı özellikler için Tahirova$2000 \times$ Tosunbey popülasyonunda da benzer bir değişim gözlenmiştir. Başaklanma gün sayıs1 122-142 gün, bitki boyu ise $82-125 \mathrm{~cm}$ arasında değişmiştir. Mevcut sonuçlar popülasyonlarda bitki boyu ve başaklanma süresi için çavdar translokasyonu taşıyan hatlar arasında geniş bir fenotipik değişimin gözlendiğini göstermektedir. Ayrıca buğdayda başaklanma süresi ve bitki boyu özellikleri transgresif açılımın en çok gözlendiği özelliklerdir. Tosunbey $\times$ Tahirova-2000 popülasyonunda çavdar translokasyonu taşıyan hatlar içerisinde GluA3b taşıyan hatların SDS sedimentasyon değeri $32 \mathrm{ml}$ iken, GluA3e alleli taşıyan hatların SDS sedimentasyon değeri $27 \mathrm{ml}$ olarak gerçekleşmiştir. Tahirova-2000 × Tosunbey popülasyonunda da benzer bir sonuç gözlenmiştir. Buna göre bu popülasyondaki değerler GluA3b taşıyan hatlar için $28 \mathrm{ml}$, GluA3e alleli taşıyan hatlar için $24 \mathrm{ml}$ olarak gerçekleşmiştir. Elde edilen sonuçlar GluA3b allelinin varlığının her iki lokasyonda da protein kalitesini olumlu yönde etkilediğini göstermektedir. Benzer sonuçlar diğer bazı araştırmacılar tarafından da bildirilmiştir (Masci ve ark., 2000; Tanaka ve ark., 2005, Ikeda ve ark., 2006; Ito ve ark., 2015). 
Çizelge 6. Tosunbey $\times$ Tahirova-2000 popülasyonunda YMA ve DMA glutenin alt ünitelerinin bazı kalite özelliklerine etkisi

Table 6. The effect of HMW-GS and LMW-GS on some quality traits in Tosunbey $\times$ Tahirova-2000 population

\begin{tabular}{lccccc}
\hline Lokus & $\begin{array}{c}\text { Alt } \\
\text { Unite }\end{array}$ & $\begin{array}{c}\text { Hat } \\
\text { sayıs1 }\end{array}$ & $\begin{array}{c}\text { Protein } \\
\text { içeriği } \\
(\%)\end{array}$ & $\begin{array}{c}\text { Kül oranı } \\
(\%)\end{array}$ & $\begin{array}{c}\text { L renk } \\
\text { değeri }\end{array}$ \\
\hline \multirow{2}{*}{ Glu-A1 } & 1 & 104 & 12.1 & 1.74 & 84.5 \\
& $2^{*}$ & 111 & 12.2 & 1.75 & 84.3 \\
\cline { 2 - 6 } Glu-B1 & $7+9$ & 98 & 12.2 & 1.74 & 84.4 \\
& $17+18$ & 117 & 12.1 & 1.75 & 84.3 \\
\cline { 2 - 6 } Glu-A3 & $\mathrm{b}$ & 108 & 12.1 & 1.75 & 84.3 \\
& $\mathrm{e}$ & 107 & 12.2 & 1.74 & 84.3 \\
\hline \multirow{2}{*}{ Glu-B3 } & $\mathrm{b}$ & 131 & $12.0 \mathrm{~b}$ & $1.73 \mathrm{~b}$ & $84.5 \mathrm{a}$ \\
& $\mathrm{j}$ & 84 & $12.3 \mathrm{a}$ & $1.76 \mathrm{a}$ & $84.2 \mathrm{~b}$ \\
\hline
\end{tabular}

Çizelge 7. Tosunbey $\times$ Tahirova-2000 popülasyonunda YMA ve DMA glutenin alt ünitelerinin bazı agronomik özelliklere etkisi

Table 7. The effect of HMW-GS and LMW-GS on some agronomic and quality traits in Tosunbey $\times$ Tahirova-2000 population

\begin{tabular}{|c|c|c|c|c|c|c|c|c|}
\hline Lokus & $\begin{array}{c}\text { Alt } \\
\text { Ünite }\end{array}$ & $\begin{array}{c}\text { Hat } \\
\text { sayis1 }\end{array}$ & $\begin{array}{c}\text { Tane } \\
\text { verimi } \\
\left(\mathrm{kg} \mathrm{da}^{-1}\right)\end{array}$ & $\begin{array}{l}\text { Bitki } \\
\text { boyu } \\
(\mathrm{cm})\end{array}$ & $\begin{array}{l}\text { Başaklanma } \\
\text { gün sayıs1 } \\
\text { (gün) }\end{array}$ & $\begin{array}{c}\text { SDS } \\
\text { Sedim. } \\
\text { Değeri } \\
(\mathrm{ml})\end{array}$ & $\begin{array}{l}\text { Hektolitre } \\
\text { ağıllığ } 1 \\
\text { (kg) }\end{array}$ & $\begin{array}{c}1000 \\
\text { tane } \\
\text { ağırlı }{ }_{1}{ }_{1} \\
(\mathrm{~g})\end{array}$ \\
\hline \multirow{2}{*}{ Glu-Al } & 1 & 202 & $415 \mathrm{a}$ & $103.9 \mathrm{a}$ & 133.1 & 32.0 & 81.7 & 41.8 \\
\hline & $2^{*}$ & 215 & $396 \mathrm{~b}$ & $101.9 \mathrm{~b}$ & 132.7 & 31.5 & 81.8 & 41.8 \\
\hline \multirow{2}{*}{ Glu-B1 } & $7+9$ & 204 & 397 & 103.0 & 133.4 & 31.6 & 81.7 & 41.9 \\
\hline & $17+18$ & 213 & 414 & 102.8 & 132.5 & 31.9 & 81.7 & 41.6 \\
\hline \multirow{2}{*}{ Glu-A3 } & $\mathrm{b}$ & 204 & 398 & 102.7 & 132.8 & $33.9 \mathrm{a}$ & 81.6 & $41.4 \mathrm{~b}$ \\
\hline & $\mathrm{e}$ & 213 & 413 & 103.1 & 133.0 & $29.6 \mathrm{~b}$ & 81.8 & $42.2 \mathrm{a}$ \\
\hline \multirow{2}{*}{ Glu-B3 } & $\mathrm{b}$ & 232 & 395 & 103.3 & 132.8 & $34.1 \mathrm{a}$ & $81.5 \mathrm{~b}$ & $40.7 \mathrm{~b}$ \\
\hline & $\mathrm{j}$ & 185 & 415 & 102.5 & 133.0 & $29.4 \mathrm{~b}$ & $82.0 \mathrm{a}$ & $42.8 \mathrm{a}$ \\
\hline
\end{tabular}

Çizelge 8. Tahirova-2000 x Tosunbey popülasyonda YMA ve DMA glutenin alt ünitelerinin bazı kalite özelliklerine etkisi

Table 8. The effect of HMW-GS and LMW-GS on some quality traits inTahirova-2000 x Tosunbey population

\begin{tabular}{cccccc}
\hline Lokus & Alt Ünite & Hat sayıs1 & $\begin{array}{c}\text { Protein içeriği } \\
(\%)\end{array}$ & $\begin{array}{c}\text { Kül oranı } \\
(\%)\end{array}$ & $\begin{array}{c}\text { L renk } \\
\text { değeri }\end{array}$ \\
\hline \multirow{2}{*}{ Glu-A1 } & 1 & 194 & 11.9 & 1.77 & $84.0 \mathrm{a}$ \\
& $2 *$ & 150 & 11.8 & 1.80 & $83.7 \mathrm{~b}$ \\
\cline { 2 - 6 } Glu-B1 & $7+9$ & 170 & 11.8 & 1.79 & 83.9 \\
& $17+18$ & 174 & 11.9 & 1.79 & 83.8 \\
\cline { 2 - 6 } Glu-A3 & $\mathrm{b}$ & 185 & $11.7 \mathrm{~b}$ & 1.79 & 83.9 \\
& $\mathrm{e}$ & 159 & $12.0 \mathrm{a}$ & 1.79 & 83.9 \\
\cline { 2 - 6 } Glu-B3 & $\mathrm{b}$ & 207 & $11.7 \mathrm{~b}$ & 1.79 & 83.8 \\
& $\mathrm{j}$ & 137 & $12.0 \mathrm{a}$ & 1.78 & 83.9 \\
\hline
\end{tabular}


Çizelge 9. Tahirova-2000 x Tosunbey popülasyonunda YMA ve DMA glutenin alt ünitelerinin bazı agronomik özelliklere etkisi

Table 9. The effect of HMW-GS and LMW-GS on some agronomic and quality traits in Tahirova-2000 x Tosunbey population

\begin{tabular}{ccccccccc}
\hline \multirow{2}{*}{ Lokus } & $\begin{array}{c}\text { Alt } \\
\text { Ünite }\end{array}$ & $\begin{array}{c}\text { Hat } \\
\text { sayıs1 }\end{array}$ & $\begin{array}{c}\text { Tane } \\
\text { verimi } \\
(\mathrm{kg} / \mathrm{da})\end{array}$ & $\begin{array}{c}\text { Bitki } \\
\text { boyu } \\
(\mathrm{cm})\end{array}$ & $\begin{array}{c}\text { Başaklanma } \\
\text { gün sayıs } \\
\text { (gün) }\end{array}$ & $\begin{array}{c}\text { SDS } \\
\text { Sedim. } \\
\text { Değeri (ml) }\end{array}$ & $\begin{array}{c}\text { Hektolitre } \\
\text { ağırlığ1 (kg) }\end{array}$ & $\begin{array}{c}1000 \text { tane } \\
\text { ağırlığ }(\mathrm{g})\end{array}$ \\
\hline \multirow{3}{*}{ Glu-A1 } & 1 & 194 & $346 \mathrm{a}$ & $104.3 \mathrm{a}$ & 133.1 & 28.2 & $79.0 \mathrm{a}$ & 36.5 \\
& $2^{*}$ & 150 & $307 \mathrm{~b}$ & $101.7 \mathrm{~b}$ & 132.1 & 27.8 & $78.2 \mathrm{~b}$ & 35.6 \\
\cline { 2 - 9 } Glu-B1 & $7+9$ & 170 & 330 & $103.5 \mathrm{a}$ & $134.0 \mathrm{a}$ & $27.3 \mathrm{~b}$ & 78.6 & 36.1 \\
& $17+18$ & 174 & 323 & $102.5 \mathrm{~b}$ & $131.2 \mathrm{~b}$ & $28.7 \mathrm{a}$ & 78.6 & 36.0 \\
\cline { 2 - 9 } Glu-A3 & $\mathrm{b}$ & 185 & 328 & 103.0 & 132.6 & $29.7 \mathrm{a}$ & 78.6 & 35.8 \\
& $\mathrm{e}$ & 159 & 325 & 103.0 & 132.6 & $26.4 \mathrm{~b}$ & 78.6 & 36.3 \\
\cline { 2 - 9 } Glu-B3 & $\mathrm{b}$ & 207 & 329 & 103.0 & 132.7 & $29.8 \mathrm{a}$ & 78.3 & $35.4 \mathrm{~b}$ \\
& $\mathrm{j}$ & 137 & 324 & 103.0 & 132.5 & $26.3 \mathrm{~b}$ & 78.9 & $36.7 \mathrm{a}$ \\
\hline
\end{tabular}

\section{Sonuç}

Tosunbey $\times$ Tahirova-2000 popülasyonunda ortalama tane verimi $399.5 \mathrm{~kg} \mathrm{da}^{-1}$, Tahirova-2000 $\times$ Tosunbey popülasyonunda ise $328.9 \mathrm{kgda}^{-1}$ olarak gerçekleşmiştir. Her iki popülasyonda da tane verimi bakımından geniş bir varyasyon söz konusudur. Geniş bir değişim aralığı da bitki boyu ve başaklanma süresinde ortaya çıkmış, başaklanma süresi 118-145 gün, bitki boyu ise 78-126 cm arasında değişmiştir. Başaklanma süresi bakımından transgresif açılım geç başaklanma için daha fazla gerçekleşirken, bitki boyu için kısa boyluluk yönünde gerçekleşmiştir. Başaklanma süresi ve bitki boyu buğdayda transgresif açılımın en çok görüldüğü özellikler arasındadır. Bu kapsamda popülasyonlarda gerek verim potansiyeli yüksek, gerekse düşük alanlara adapte olabilecek hatlar taşıdığı söylenebilir.

Gerek kolay ölçülebilmesi gerekse kalite konusunda güvenilir ve anlamlı sonuçlar vermesi açısından hektolitre ağırlığı ve SDS sedimantasyon değeri en sık kullanılan kalite kriterleri arasında yer almaktadır. Tosunbey $\times$ Tahirova-2000 popülasyonunda yer alan hatlardan 72 tanesi Tosunbey çeşidinden daha yüksek SDS sedimantasyon değerine $(36 \mathrm{ml})$ sahip olurken, Tahirova-2000 $\times$ Tosunbey popülasyonunda elde edilen hatların 95 tanesi Tosunbey çeşidinden daha yüksek SDS sedimantasyon değerine sahip olmuştur. Tosunbey $\times$ Tahirova-2000 popülasyonunda SDS sedimantasyon oranı yüksek olan hat sayısı fazla olmakla birlikte her iki popülasyonda da bu özellik bakımından geniş bir değişim söz konusudur. Tosunbey çeşidi Türkiye sslah programlarında geliştirilen ve ekmeklik kalitesi çok yüksek olan bir çeşittir. Çeşidin protein kalitesinin yüksek olmasında, taşımış olduğu YMA glutenin alt üniteleri yanında DMA glutenin alt üniteleri için her üç lokusta da $b$ allelini taşıyor olması etkilidir. Tahirova-2000 çeşidi de geniş adaptasyon yeteneği ve yüksek verim potansiyeli ile uzun yıllar Türkiye buğday tarımında kullanılmıştır. Tahirova-2000 çeşidi DMA glutenin alt üniteleri için GluA3e (null), GluB3j, GluD3b allellerini ve çavdar translokasyonu taşımaktadır (Çizelge 1 ve Şekil 1). Her iki çeşidin de DMA glutenin alt üniteleri ilk kez bu araştırmada rapor edilmiştir. Ortalama hektolitre ağırlığı Tosunbey $\times$ Tahirova-2000 popülasyonunda $81.7 \mathrm{~kg}$, Tahirova-2000 × Tosunbey popülasyonunda ise $78.3 \mathrm{~kg}$ olarak gerçekleşmiştir. Hektolitre ağırlığ 78 kg'ın üzerinde olan hat sayıs Tosunbey $\times$ Tahirova-2000 popülasyonunda 372 adet (\% 98), Tahirova-2000 $\times$ Tosunbey popülasyonunda 216 adettir (\% 61). Ayrıca her iki popülasyonda da bin tane ağırlığı bakımından geniş bir değişim aralı̆̆ı ortaya çıkmıştır (31.3-55.3 g ve 27.0-48.3 g).

Samsun'da her yıl olduğu gibi yoğun bir epidemi göstermiş ve her iki popülasyonda da külleme okumaları normal dağ 1 lım göstermiştir. Bu çalışmada, Tahirova-2000 çeşidinde küllemeye dayanıklılık bakımından birden fazla gen bulunduğu ve çeşidin olgun bitki dayanıklılığı gösterdiği anlaşılmaktadır.

Araştırma sonucunda resiprokal olarak geliştirilen rekombinant kendilenmiş hat popülasyonunda moleküler olarak taranan hatlardan 324 adedinin çavdar translokasyonu taşıdığı saptanmıştır. Bu hatların bitki boyu, başaklanma gün sayısı ve SDS sedimentasyon değerleri bakımından oluşturulması planlanan alt popülasyonlara uygun fenotipik değişime sahip olduğu gözlenmiştir. GluA3b alleli taşıyan hatların ortalama SDS sedimentasyon değerleri her iki popülasyonda da GluA3e alleli taşıyan hatlardan daha yüksek bulunmuş olması ile GluA3b allelinin ekmeklik buğdayda protein kalitesinin artırılması için kullanılabileceği öngörülmektedir. Çalışmada, araştırma materyali olarak kullanılan haritalama popülasyonlarının, daha sonra yapılacak kuraklığa tolerans ve kalite 1slahı araştırmaları için moleküler ve fenotipik değişime sahip olduğu saptanmıştır. Ayrıca mevcut veriler, elde edilen 429 
popülasyonların moleküler çalışmalarda haritalama veya markör geliştirme çalışmalarında kullanılabileceğini göstermektedir.

\section{Teşekkür}

Bu araştırmanın 109O233 ve $215 \mathrm{O} 608$ numaralı TÜBİTAK hızlı destek projeleri kapsamında yürütülmüş olması nedeniyle TÜBİTAK'a ve SDS-PAGE jellerinde DMA glutenin alt ünitelerinin okunmasındaki katkılarından dolayı Japonya'dan (National Institute for Agro-Environmental Sciences) Dr. Tatsuya M. Ikeda'ya teşekkür ederiz.

\section{Kaynaklar}

Anonim, 1990. Cereals. PBI Cambridge, Plant Breeding International, Cambridge.

Anonim, 2010. Industry Brifing Paper. Test Weight of AustralianWheat 2010 and Beyond, Page 5. GrainTradeAustralia. PO Box R1829, Royal Exchange NSW 1225.

Assanga, S.O., Fuentealba, M., Zhang,G., Tan, C.,Dhakal, S., Rudd, J.C., Ibrahim, A.M.H., Xue, Q., Haley, S., Chen, J., Chao, S., Baker, J., Jessup, K., Liu, S., 2017. Mapping of Quantitative Trait Loci for GrainYield and Its Components in A Us Popular Winter Wheat TAM doi: 10.1371/journal.pone.0189669

Atlı, A., 1999. Buğday ve Ürünleri Kalitesi. Orta Anadolu'da Hububat Tarımının Sorunları ve Çözüm Yolları Sempozyumu, 8-11 Haziran, Konya.

Aydın, N., TÜBİTAK Projesi Sonuç Raporu, Proje No: $112 \mathrm{O} 135$.

Baenziger, P.S., Shelton, D.R., Shipman, M.J., Graybosch, R.A., 2001. Breeding for End Use Quality: Reflections on The Nebraska Experience. Euphytica, 119 (4): 95-100. doi.org/10.1023/A:1017583514424

Basavaraddi, P.A., Savini, R., Sukumaran, S., Reynolds, M., Griffiths, S., Slafer, G., 2021. Genotypic Differences in Wheat Yield Determinants Within A NAM Population Based on Elite Parents. European Journal of Agronomy, 123:1626. doi: https://doi.org/10.1101/2020.09.08.287763

Blade, S.F., Baker, R.J., 1991. Kernel Weight Response to Source Sink Changes in Spring Wheat Crop Sci, 31: 1117-1120.

Bohn, M., Utz, H.F., Melchinger, A.E., 1998. Genetic Similarities Among Winter Wheat Cultivars Determined on The Basis of RFLPs, AFLPs and SSRs and Their Use for Predicting Progeny Variance. Crop Sci, 39 (1): 228 237.

Bonafede, M.D., Tranquilli, G., Pflüger, L.A., Pena, R.J., Dubcovsky, J., 2015. Effect of Allelic Variation at The Glu-3/Gli-1 Loci On Breadmaking Quality Parameters in Hexaploid Wheat (Triticum aestivum L.). J Cereal Sci, 62: 143-150.

Brim, C.A., 1966. A Modified Pedigree Method of Selection in Soybeans. Crop Sci, 6: 220. doi:10.3906/tar-10111474

Butow BJ, Ma W, Gale KR, Cornish GB, Rampling L, Larroque O, Morell MK, Békés F 2003. Molecular Discrimination of Bx7 Alleles Demonstrates That a Highly Expressed High Molecular Weight Glutenin Allele Has a Major Impact on Wheat Flour Dough Strength. Theoretical and Applied Genetics 107: 1524-1532.

Cook, R.J., 1992. Wheat Root Heath Management and Environmental Concern. Can. J. Plant Pathol, 14: 76-85.

Costa, J.M., Kronstad, W.E., 1994. Association of Grain Protein Concentration and Selected Traits in Hard Red Winter Wheat Populations in The Pacific Northwest. Crop Sci, 34: 1234-1239. doi.org/10.2135/cropsci1994.00111

D’Ovidio, R., Masci, S., 2004. The Low Molecular Weight Glutenin Subunits of Wheat Gluten. J Cereal Sci, 39 : 321-339. doi.org/10.1016/j.jcs.2003.12.002

Dhaliwal, A.S., MacRitche, F., 1990. Contributions of Protein Fractions to Dough Handling Properties of Wheat Rye Translocation Cultivars. J Cereal Sci, 12: 113-122.

Dreisigacker, S., Sukumaran, S., Guzmán, C., He, X., Bonnett, D., Crossa, J., 2016. Molecular Marker Based Selection Tools in Spring Bread Wheat Improvement: CIMMYT Experience and Prospects. Mol Breed Sustain Crop Improv, 11(3): 421-474.

Ehdaie, B., Layne, A.P., Waines, J.G., 2011. Root System Plasticity to Drought Influences Grain Yield in Bread Wheat. Euphytica, 186(4): 219-232. Doi.10.1007/s10681-011-0585-9

Espi, A., Quijano, M.R., Vazquez, J.F., Carrillo, J.M., Giraldo, P., 2014. Molecular Characterization of Glu-B3 Locus in Wheat Cultivars and Segregating Populations. J Cereal Sci, 60: 374-381.

Everts, K.L., Leath, S., Finney, P.L., 2001. Impact of Powdery Mildew and Leaf Rust on Milling and Baking Quality of Soft Red Winter Wheat. Plant Dis, 85(4): 423-429.

Faheem, M., Mahmood, T., Shabbir, G., Akhtar, N., Kazi, A., Kazi, A.M., 2015. Assessment of D-Genome Based Genetic Diversity in Drought Tolerant Wheat Germplasm. Int J Agric Biol,17: 791-796. doi:10.17957/IJAB/14.0018 
Fischer, R.A., Bidinger, F., Syme, J.R., Wall, P.C., 1981. Leaf Photosynthesis, Lead Permeability, Crop Growth, and Yield of Short Spring Wheat Genotypes Under İrrigation. Crop Sci, 21: 367-373.

Genç, İ., Yağbasanlar, T., Özkan, H., 1993. Akdeniz İklim Kuşağına Uygun Makarnalık Buğday Çeşitlerinin Belirlenmesi Üzerinde Araştırmalar. Makarnalık Buğday ve Mamülleri Sempozyumu, 30 Kasım-3 Aralık, Ankara.

Gianibelli, M.C., Lagudah, E.S., Wrigley, C.W., MacRitchie, F., 2002. Biochemical and Genetic Characterization of a Monomeric Storage Protein (T1) With an Unusually High Molecular Weight in Triticum tauschii. Theoretical and Applied Genetics, 104: 497-504. doi: 10.1007/s00122-001-0778-z

Graybosch, R.A., 2001. Uneasy Unions: Quality Effects of Rye Chromatin Tranfers to Wheat. J Cereal Sci, 33: 316.

Graybosch, R.A., Peterson, C.J., Shelton, D.R., Baenziger, P.S., 1996. Genotypic and Environmental Modification of Wheat Flour Protein Composition in Relation to End-Use Quality. Crop Sci, 36 (2): 296-300.

Griffey, C.A., Das, M.K., Stromberg, E.L., 1993. Effectiveness of Adult-Plant Resistance in Reducing Grain Yield Loss to Powdery Mildew in Winter Wheat. Plant Dis, 77: 618-622.

Guo, H., Wu, J., Lu, Y., Yan, Y., 2019. High Molecular Weight Glutenin 1Bx17 and 1By18 Subunits Encoded by Glu-B1i Enhance Wheat Dough Rheological Properties and Breadmaking Quality. J Food Quality, 15: 145153. doi.org/10.1155/2019/1958747

Güleç, T., 2020. Ekmeklik Buğdayda Geliştirilen Resiprokal Rekombinant Kendilenmiş Hat Populasyonunda Çavdar Translokasyonu Taşıyan Hatların Yarı Bodurluk, Fotoperiyod, Vernalizasyon ve Waxy Genlerinin Taraması. KMÜ, Fen Bilimleri Enstitüsü, Biyomühendislik Anabilim Dalı, Doktora Tezi, 136 sy.

Henkrar, F., El-Haddoury, J., Iraqi, D., Bendaou, N., Udupa, S.M., 2017. Allelic Variation at High Molecular Weight and Low Molecular Weight Glutenin Subunit Genes In Moroccan Bread Wheat and Durum Wheat Cultivars. 3 Biotech,3: 17-24.

Hsam, S.L., Mohler, V., Hartly, L., Wenzel, G., Zeller, F.J., 2000. Mapping of Powdery Mildew and Leaf Rust Resistance Genes on Wheat-Rye Translocated Chromosome TlBL.1RS Using Molecular ve Biochemical Markers. Plant Breeding, 119: 87-89.

Hsia, C.C., Anderson, O.D., 2001. Isolation and Characterization of Wheat $\omega$-Gliadin Genes. Theor. Appl Genet, 103(5): 37-44.

Hu, J., Wan,g X., Zhang, G., Jiang, P., Chen, W., Hao, Y., Ma, X., Xu, S., Jia, J., Kong, L., 2020. QTL Mapping For Yield Related Traits in Wheat Based on Four RIL Populations. Theor Appl Genet, 133: 917-933.

Ikeda, T.M., Araki, E., Fujita, Y., Yano, H.,2006. Characterization of Low Molecular Weight glutenin Subunit Genes and Their Protein Products Common Wheats. Theor Appl Genet, 112: 327-334.

Ito, M., 2015. Dough Properties and Bread-Making Quality-Related Characteristics of Yumechikara Near-Isogenic Wheat Lines Carrying Different Glu-B3 Alleles. Breeding Sci, 65(3): 241-248. https://doi.org/10.1270/jsbbs.65.241

JMP, 12.0.1. SAS Institute Inc., Cary, NC, 1989-2019.

Johnson, J.W., Bäenziger, P.S., Yamazaki, W.T., Smith, R.T., 1979. Effects of Powdery Mildew on Yield and Quality of Isogenic Lines of 'Chancellor' Wheat. Crop Sci, 19: 349-352.

Koyuncu, M., 2009. Yerel durum buğday çeşitlerinin makarnalık kalitelerini etkileyen önemli parametreler bakımından taranması. GOÜ, Fen Bilimleri Enstitüsü, Gıda Mühendisliği Anabilim Dalı, Yüksek Lisans Tezi, 49 sy.

Lelleya, T., Edera, C., Grausgruberb, H., 2004. Influence of 1BL.1RS Wheat-Rye Chromosome Translocation on Genotype by Environment Interaction. Journal of Cereal Science, 39(3): 313-320. doi.org/10.1016/j.jcs.2003.11.003

Lillemo, M., Asalf, B., Singh, R.P., Huerta-Espino, J., Chen, X.M., He, Z.H., Bjornstad, A., 2008. The Adult Plant Rust Resistance Loci Lr34/Yr18 and Lr46/Yr29 Are Important Determinants of Partial Resistance to Powdery Mildew in Bread Wheat Line Saar. Theor Appl Genet, 116: 1155-1166. doi: 10.1007/s00122-008-0743-1

Liu, S., Griffey, C.A., Saghai, Maroof, M.A., 2001. Identification of Molecular Markers Associated With Adult Plant Resistance to Powdery Mildew in Common Wheat Cultivar Massey. Theor Appl Genet, 41: 1268-1275.

Maghirang, E.B., Lookhart, G.L., Bean, S.R., Pierce, R.O., Xie, F., Caley, M.S., Wilson, J.D., Seabourn, B.W., Ram, M.S., Park, S.H., Chung, O.K., Dowell, F.E., 2006. Comparison of Quality Characteristics and Breadmaking Functionality of Hard Red Winter and Hard Red Spring Wheat. Cereal Chemistry, 83: 520-528.

Major, D.J., Janzen, H.H., Sadasivalah, R.S., Carefoot, J.M., 1992. Morphological Characters of Wheat Associated With High Productivity. Can J of Plant Sci, 72: 689-698. doi:10.4141/cjps92-085

Martin, D.J., Stewart, B.G., 1990. Dough Stickiness In Rye-Derived Wheat Cultivars. Euphytica, 51: 77-86.

Masci, S., D’Ovidio, R., Lafiandra, D., Kasarda, D.D., 2000. A 1B-Coded Low Molecular Weight Glutenin Subunit Associated With Quality in Durum Wheats Shows Strong Similarity to a Subunit Present In Some Bread Wheat Cultivars. Theo and Appl Genetics, 100: 396-400. doi.org/10.1007/s001220050052 
McClung, A.M., Cantrell, R.G., Quick, J.S., Gregory, R.S., 1986. Influence of The Rht1 Semi-Dwarf Gene on Yield, Yield Components, and Grain Protein in Durum Wheat Crop Sci, 26: 1095-1099.

Moiraghi, M., Vanzetti, L., Pflüger, L., Helguera, M., Perez, G.T., 2013. Effect of High Molecular Weight Glutenins and Rye Translocations on Soft Wheat Flour Cookie Quality. Journal of Cereal Sci, 58: 424-430.

Moonen, J.E., Scheepstra, A., Graveland, A., 1982. Use of the SDS- Sedimentation Test and SDSPolyacrylamidegel Electrophoresis for Screening Breeder's Samples of Wheat for Breadmaking Quality. Euphytica, 31: 677-690.

Mut, Z., Aydın, N., Bayramoğlu, N.O., Özcan, H., 2007. Bazı ekmelik buğday (Triticum aestivum L.) genotiplerinin verim ve başlıca kalite özelliklerinin belirlenmesi. OMÜ Ziraat Fakültesi Dergisi, 22(2): 193-201.

Özkan, H., TÜBİTAK Projesi Sonuç Raporu, Proje No: 107020.

Payne, P.I., Nightingale, M.A., Krattiger, A.F., Holt, L.M., 1987. The Relationship Between HMW Glutenin Subunit Composition and The Bread-Making Quality of British-Grown Wheat Varieties. J Sci Food Agric, 40: 51-65.

Peterson, C.J., Graybosch, R.A., Baenziger, P.S., Grombacher, A.W., 1992. Genotype and Environment Effects on Quality Characteristics of Hard Red Winter Wheat. Crop Sci, 32: 98-103. doi:10.2135/cropsci1992.0011183X003200010022x

Poland, J.A., Brown. P.J., Sorrells, M.E., Jannink, J.L., 2012. Development of High-Density Genetic Maps for Barley and Wheat Using A Novel Two-Enzyme Genotyping By Sequencing Approach. PLoS ONE 7: 32253.

Rabinovich, S., 1998. Importance Of Wheat-Rye Translocations for Breeding Modern Cultivars of Triticum aestivum L. Klawer Akademic Publishers,100: 401-418. doi.org/10.1023/A:1018361819215

Ram, S., Sharma, S., Verma, A., Tyagi, B.S., Pena, R.J., 2011. Comparative Analyses of LMW Glutenin Alleles in Bread Wheat Usign Allele-Specific PCR and SDS-PAGE. J Cereal Sci, 54: 488-493.

Reynolds, M., Foulkes, J., Furbank, R., 2012. Achieving Yield Gains in Wheat. Plant Cell Environtal, 35: 17991823.

Roelfs, A.P., Singh, R.P., Saari, E.E., 1992. Rust Disease of Wheat: Concepts and Methods of Disease Management. Mexico, CIMMYT 81.

Saari, E.E., Prescott, J.M., 1975. A Scale for Appraising The Foliar Intensity of Wheat Diseases. Plant Dis Rep, 59(5): 377-380.

Sade, B., Topal, A., Soylu, S., 1999. Konya Sulu Kosullarinda Yetistirilebilecek Makarnalik Buğday Çesitlerinin Belirlenmesi. Orta Anadolu'da Hububat Tarımının Sorunları ve Çözüm Yolları Sempozyumu, 8- 11 Haziran, Konya.

Sayaslan, A., Seib, P.A., Chung, O.K., 2006. Wet-Milling Properties of Waxy Wheat Flours by Two Laboratory Methods. Journal of Food Engineering, 72: 167-178.

Schuler, S.F., Bacon, R.K, Gbur, E.E., 1994. Kernel And Spike Character Influence on Test Weight of Soft Red Winter Wheat Crop Sci, 34: 1309-1313. doi.org/10.2135/cropsci1994.0011183X003400050031x

Singh, N.K., Shepherd, K.W., Cornish, G.B., 1991. A Simplified SDS-PAGE Procedure for Separating LMW Subunits of Glutenin. Journal of Cereal Science, 14: 203-208.

Summers, R., Payne, P.I., 1997. Inter Wheat Quality Res,3: 185-191.

Tanaka, H., Shimizu, R., Tsujimoto, H., 2005. Genetical Analysis of Contribution of Low Molecular Weight Glutenin Subunits to Dough Strength in Common Wheat (Triticum aestivum L.). Euphytica, 141: 157-162.

Tavella, C.M., 1978. Date of Heading and Plant Height of Wheat Varieties as Related to Septoria Leaf Blotch Damage. Euphitica, 27: 577-580 doi.org/10.1007/BF00043184

Wilhelm, E.P., Boulton, M.I., Al-Kaff, N., Balfourier, F., Bordes, J., Greenlve, A.J., 2013. Rht-1 and Ppd-D1 Associations With Height, Ga Sensitivity, and Days to Heading In a Worldwide Bread Wheat Collection. Theor Appl Genet., 126(1): 2233-2243.

Yıldırım, A., Sakin, M.A., Karadag, Y., Gokmen, S., Kandemir, N., Akkaya, M.S., Yildirim, F., 2004. Genetic Marker Mediated Transfer of an Alien Gene, Pm21, Into Wheat Conferring Resistance to Powdery Mildew. Biotechnol Biotechnol Equip, 18(3):15-19 doi.org/10.1080/13102818.2004.10817081

Zeller, F.J., Hsam, S.L.K., 1984. Broadening The Genetic Variability of Cultivated Wheat by Utilizing Rye Chromatin. Proc 6th Int Wheat Genetic, Symp,Kyoto, Japan. 